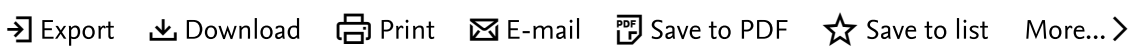

View at Publisher

2020 3rd International Seminar on Research of Information Technology and Intelligent Systems, ISRITI 2020

10 December 2020, Article number 9315436, Pages 321-325

3rd International Seminar on Research of Information Technology and Intelligent Systems, ISRITI

2020; STMIK Akakom Yogyakartajalan Raya Janti No 143, Karang Jambe, Banguntapan Yogyakarta;

Indonesia; 10 December 2020 through ; Category numberCFP20AAH-ART; Code 166521

\title{
Some Numerical and Analytical Solutions to an Enzyme-Substrate Reaction-Diffusion Problem (Conference Paper)
}

Mungkasi, S. $\nabla \stackrel{\square}{ }$



Sanata Dharma University, Faculty of Science and Technology, Department of Mathematics, Yogyakarta, Indonesia

View additional affiliations $\vee$

\section{Abstract}

We consider an enzyme-substrate reaction-diffusion problem. Unsteady and steady state models are recalled. For the unsteady state case, the model is in the form of a second order partial differential equation. We solve the unsteady state model using the explicit numerical finite difference method, which is forward difference in time and centered difference in space. For the general steady state case, the model is in the form of a second order ordinary differential equation. We solve the general steady state model using the explicit first order Euler's numerical method. For the particular steady state case of the unsaturated catalytic kinetics, we derive the exact analytical solution using the characteristic method of ordinary differential equations. For the particular steady state case of the saturated catalytic kinetics, we derive the exact analytical solution using the direct-integration method. The obtained exact analytical solutions are identical with the existing exact analytical solutions derived using the variational iteration method. With the aid of computer, the enzyme-substrate reaction-diffusion problem can be solved and simulated successfully for both unsteady and steady state cases. (C) 2020 IEEE.

\section{Author keywords}



Indexed keywords

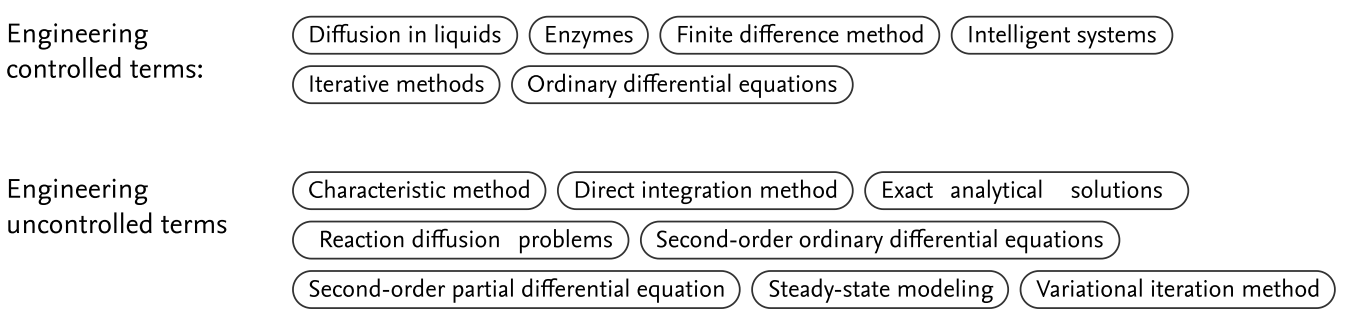

Engineering main

heading:

DOI: 10.1109/ISRITI51436.2020.9315436

Document Type: Conference Paper

Volume Editors: Wibowo F.W.

Publisher: Institute of Electrical and Electronics Engineers Inc. 
https://ieeexplore.ieee.org/document/9315436






\begin{tabular}{|c|c|c|c|c|c|c|c|c|}
\hline IEEE.org & IEEE Xplore & IEEE-SA & IEEE Spectrum & More Sites & SUBSCRIBE & SUBSCRIBECart & Create Account & Personal Sign \\
\hline
\end{tabular}

Institutional Sign In

All

ADVANCED SEARCH

Conferences > 2020 3rd International Semina...

\section{Some Numerical and Analytical Solutions to an Enzyme- Substrate Reaction-Diffusion Problem}

Publisher: IEEE Cite This Pite This

Sudi Mungkasi All Authors

7

Text Views

\section{Abstract}

Document Sections

I. Introduction

II. Mathematical Models and Their Properties

III. Numerical Methods

IV. Numerical

Results and

Discussion

v. Conclusion

Authors

Figures

References

Keywords

Metrics

More Like This
Abstract:We consider an enzyme-substrate reaction-diffusion problem. Unsteady and steady state models are recalled. For the unsteady state case, the model is in the form of a seco... View more

\section{Metadata}

Abstract:

We consider an enzyme-substrate reaction-diffusion problem. Unsteady and steady state models are recalled. For the unsteady state case, the model is in the form of a second order partial differential equation. We solve the unsteady state model using the explicit numerical finite difference method, which is forward difference in time and centered difference in space. For the general steady state case, the model is in the form of a second order ordinary differential equation. We solve the general steady state model using the explicit first order Euler's numerical method. For the particular steady state case of the unsaturated catalytic kinetics, we derive the exact analytical solution using the characteristic method of ordinary differential equations. For the particular steady state case of the saturated catalytic kinetics, we derive the exact analytical solution using the direct-integration method. The obtained exact analytical solutions are identical with the existing exact analytical solutions derived using the variational iteration method. With the aid of computer, the enzyme-substrate reaction-diffusion problem can be solved and simulated successfully for both unsteady and steady state cases.

Published in: 2020 3rd International Seminar on Research of Information Technology and Intelligent Systems (ISRITI)

Date of Conference: 10-11 Dec. 2020

DOI: 10.1109/ISRITI51436.2020.9315436

Date Added to IEEE Xplore: 13 January Publisher: IEEE 2021

ISBN Information:
Conference Location: Yogyakarta, Indonesia, Indonesia
More Like This

Numeric Model of Power Linear Ordin Differential Equation

2010 Ninth International Symposium Distributed Computing and Applicatio Business, Engineering and Science Published: 2010

Investigation on Steady-State and Transient Boundary Condition Scenar for Optimizing the Creation of Multipo Surrogate Thermal Models

IEEE Transactions on Components, Packaging and Manufacturing Techno Published: 2018 


\begin{abstract}
I. Introduction
Chemical reaction problems may incorporate diffusion. This process is then called a reaction-diffusion problem. The reaction-diffusion process has been modelled into a mathematical equation. The derivation involves the so called Michaelis-Menten kinetics. The Michaelis-Menten kinetics itself has been widely recognised in chemistry for reaction problems [1]-[7].
\end{abstract}

\begin{tabular}{lc} 
Authors & $\checkmark$ \\
\hline Figures & $\checkmark$ \\
\hline References & $\checkmark$ \\
\hline Keywords & $\vee$ \\
\hline Metrics & $\vee$
\end{tabular}

$\begin{array}{llll}\text { CHANGE USERNAME/PASSWORD } & \text { PAYMENT OPTIONS } & \text { COMMUNICATIONS PREFERENCES } & \text { US \& CANADA: +1 } 800 \text { 678 4333 } \\ & \text { VIEW PURCHASED DOCUMENTS } & \text { PROFESSION AND EDUCATION } & \text { WORLDWIDE: +1 732 981 0060 } \\ & & \text { TECHNICAL INTERESTS } & \text { CONTACT \& SUPPORT }\end{array}$

About IEEE Xplore Contact Us Help Accessibility Terms of Use Nondiscrimination Policy Sitemap Privacy \& Opting Out of Cookies

\begin{tabular}{|c|c|c|c|}
\hline IEEE Account & Purchase Details & Profile Information & Need Help? \\
\hline »Change Username/Password & » Payment Options & »Communications Preferences & »US \& Canada: +1 8006784333 \\
\hline » Update Address & » Order History & »Profession and Education & "Worldwide: +1 7329810060 \\
\hline & „View Purchased Documents & » Technical Interests & »Contact \& Support \\
\hline
\end{tabular}

About IEEE Xplore Contact Us Help Accessibility Terms of Use Nondiscrimination Policy Sitemap Privacy \& Opting Out of Cookies 
Institutional Sign In

\section{Quick Links}

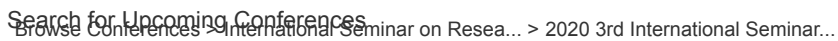

IEEE Publication Recommender

\section{?}

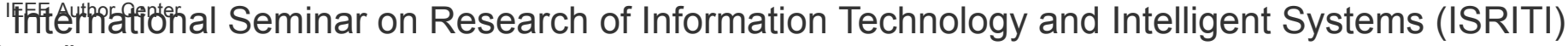

Proceedings

The proceedings of this conference will be available for purchase through Curran Associates.

Research of Information Technology and Intelligent Systems (ISRITI), 2020 3rd International Seminar on

\# Copy Persistent Link $\quad$ : B Browse Title List

Print on Demand Purchase at Partner

External Hard-drive Purchase at Partner
Proceedings All Proceedings

2020 3rd International Seminar on Research of Information Technology and Intelligent Systems (ISRITI)

DOI: $10.1109 / I S R I T I 51436.2020$

Search within results

Per Page: IEPer Page 25 | Export | Email Selected Results

Showing $101-125$ of 144

$\checkmark$ Filter

sort: IESort Sequence

\section{Refine}

\begin{tabular}{ll}
\hline Author & $\checkmark$ \\
\hline Affiliation & $\checkmark$ \\
\hline Conference Location & $\checkmark$
\end{tabular}

\section{Quick Links}

Search for Upcoming

Conferences

IEEE Publication Recommender

IEEE Author Center

Proceedings

The proceedings of this conference will be available for purchase through Curran Associates.

Research of Information Technology and Intelligent Systems (ISRITI), 2020 3rd International Seminar on

Print on Demand Purchase at Partner

External Hard-drive Purchase at Partner
Influence Distribution Training Data on Performance Supervised Machine Learning Algorithms

Ignasius Boli Suban; Andi W. R. Emanuel

Publication Year: 2020 , Page(s): 100 - 105

$$
\text { Abstract } \quad(355 \mathrm{~Kb})
$$

Influence Distribution Training Data on Performance Supervised Machine Learning Algorithms

Ignasius Boli Suban; Andi W. R. Emanuel

2020 3rd International Seminar on Research of Information Technology and Intelligent Systems (ISRITI)

Year: 2020

Prototype Design of IoT (Internet of Things)-based Load Monitoring System Husein Mubarok; Agus Ardiansyah

Publication Year: 2020 , Page(s): 377 - 382

Abstract $\quad(549 \mathrm{~Kb})$

Prototype Design of IoT (Internet of Things)-based Load Monitoring System

Husein Mubarok; Agus Ardiansyah

2020 3rd International Seminar on Research of Information Technology and Intelligent Systems (ISRITI)

Year: 2020

Detection of Multi-Class Glaucoma Using Active Contour Snakes and Support Vector Machine

Fakhira Zahra Zulfira; Suyanto Suyanto

Publication Year: 2020 , Page(s): 650 - 654
Abstract
$(659 \mathrm{~Kb})$

Detection of Multi-Class Glaucoma Using Active Contour Snakes and Support Vector Machine

Fakhira Zahra Zulfira; Suyanto Suyanto

2020 3rd International Seminar on Research of Information Technology and

Intelligent Systems (ISRITI)

\section{Need}

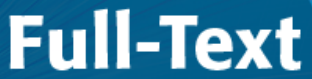

access to IEEE Xplore

for your organization?

CONTACT IEEE TO SUBSCRIBE $>$
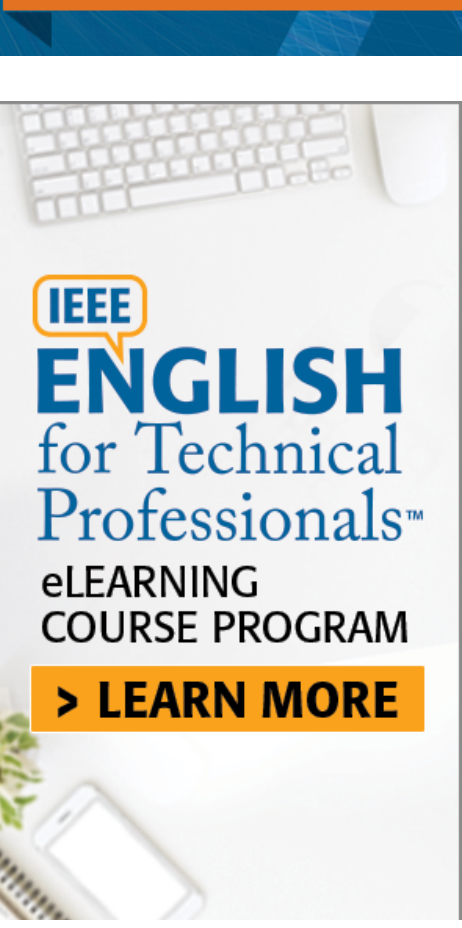
Energy Management Efficiency and Stability Using Passive Filter in Standalone Photovoltaic Sudden Cloud Condition

Rezi Delfianti; Adi Soeprijanto; Ardyono Priyadi; Avian Lukman Setya Budi; Imam

Abadi

Publication Year: 2020 , Page(s): 716 - 720
Abstract
(915 Kb)

Energy Management Efficiency and Stability Using Passive Filter

in Standalone Photovoltaic Sudden Cloud Condition

Rezi Delfianti; Adi Soeprijanto; Ardyono Priyadi; Avian Lukman Setya

Budi; Imam Abadi

2020 3rd International Seminar on Research of Information Technology and Intelligent Systems (ISRITI)

Year: 2020

Analysis of Indonesia's Internet Topology Borders at the Autonomous System Level

Timotius Witono; Setiadi Yazid

Publication Year: 2020 , Page(s): 545 - 550

Abstract (572 Kb)

Analysis of Indonesia's Internet Topology Borders at the Autonomous System Level

Timotius Witono; Setiadi Yazid

2020 3rd International Seminar on Research of Information Technology and

Intelligent Systems (ISRITI)

Year: 2020

Some Numerical and Analytical Solutions to an Enzyme-Substrate ReactionDiffusion Problem

Sudi Mungkasi

Publication Year: 2020 , Page(s): 321 - 325

Abstract $\quad(307 \mathrm{~Kb})$

We consider an enzyme-substrate reaction-diffusion problem. Unsteady and steady state models are recalled. For the unsteady state case, the model is in the form of a second order partial differential equation. We solve the unsteady state model using the explicit numerical finite difference method, which is forward difference in time and centered difference in space. For the general steady state ca... Show More

Some Numerical and Analytical Solutions to an Enzyme-

Substrate Reaction-Diffusion Problem

Sudi Mungkasi

2020 3rd International Seminar on Research of Information Technology and Intelligent Systems (ISRITI)

Year: 2020

Network Attack Detection System Using Filter-based Feature Selection and SVM

Ventje Jeremias Lewi Engel; Firhat Hidayat; Richard Dwiputra

Publication Year: 2020 , Page(s): 203 - 208

Abstract $\quad(497 \mathrm{~Kb})$

Network Attack Detection System Using Filter-based Feature

Selection and SVM

Ventje Jeremias Lewi Engel; Firhat Hidayat; Richard Dwiputra

2020 3rd International Seminar on Research of Information Technology and

Intelligent Systems (ISRITI)

Year: 2020

Modification of Wireless Reverse Charging Scheme with Bundling Optimization

Issues

Fitri Maya Puspita; Ayu Wulandari; Evi Yuliza; Robinson Sitepu; Yunita

Publication Year: 2020 , Page(s): 556 - 561

Abstract (372 Kb)

Modification of Wireless Reverse Charging Scheme with

Bundling Optimization Issues

Fitri Maya Puspita; Ayu Wulandari; Evi Yuliza; Robinson Sitepu; Yunita

2020 3rd International Seminar on Research of Information Technology and

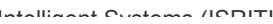


ıntenıent systems (ISkıוI)

Year: 2020

Guided Genetic Algorithm to Solve University Course Timetabling with Dynamic Time Slot

Muhammad Fachrie; Anita Fira Waluyo

Publication Year: 2020 , Page(s): 583 - 587

Abstract $\quad(327 \mathrm{~Kb})$

Guided Genetic Algorithm to Solve University Course

Timetabling with Dynamic Time Slot

Muhammad Fachrie; Anita Fira Waluyo

2020 3rd International Seminar on Research of Information Technology and

Intelligent Systems (ISRITI)

Year: 2020

Website Design for Locating Tuna Fishing Spot Using Naïve Bayes and SVM

Based on VMS Data on Indonesian Sea

Hery; Samuel Lukas; Pujianto Yugopuspito; I Made Murwantara; Dion Krisnadi

Publication Year: 2020 , Page(s): 89 - 93

Abstract (1241 Kb)

Website Design for Locating Tuna Fishing Spot Using Naïve

Bayes and SVM Based on VMS Data on Indonesian Sea

Hery; Samuel Lukas; Pujianto Yugopuspito; I Made Murwantara; Dion Krisnadi

2020 3rd International Seminar on Research of Information Technology and

Intelligent Systems (ISRITI)

Year: 2020

$\square$ A Comparative Study of Java and Kotlin for Android Mobile Application

Development

Bambang Purnomosidi Dwi Putranto; Robertus Saptoto; Ovandry Chandra

Jakaria; Widyastuti Andriyani

Publication Year: 2020 , Page(s): 383 - 388

Abstract

$(947 \mathrm{~Kb})$

$\square$ A Comparative Study of Java and Kotlin for Android Mobile

Application Development

Bambang Purnomosidi Dwi Putranto; Robertus Saptoto; Ovandry Chandra

Jakaria; Widyastuti Andriyani

2020 3rd International Seminar on Research of Information Technology and

Intelligent Systems (ISRITI)

Year: 2020

A Robust Iris Segmentation Algorithm Based on Pupil Region for Visible

Wavelength Environments

Hala N. Fathee; Shaaban Sahmoud; Jassim M. Abdul-Jabbar

Publication Year: 2020 , Page(s): 655 - 660

Abstract $\quad(649 \mathrm{~Kb})$

A Robust Iris Segmentation Algorithm Based on Pupil Region for

Visible Wavelength Environments

Hala N. Fathee; Shaaban Sahmoud; Jassim M. Abdul-Jabbar

2020 3rd International Seminar on Research of Information Technology and

Intelligent Systems (ISRITI)

Year: 2020

A Modified Deep Convolutional Network for COVID-19 detection based on chest $X$-ray images

Fian Yulio Santoso; Hindriyanto Dwi Purnomo

Publication Year: 2020 , Page(s): 700 - 704

Abstract $\quad(494 \mathrm{~Kb})$

A Modified Deep Convolutional Network for COVID-19 detection based on chest $X$-ray images

Fian Yulio Santoso; Hindriyanto Dwi Purnomo

2020 3rd International Seminar on Research of Information Technology and

Intelligent Systems (ISRITI)

Year: 2020 
Publication Year: 2020 , Page(s): 439 - 444



Comparison of the Latest DTM with DEM Pleiades in Monitoring the Dynamic Peatland

Atriyon Julzarika; Trias Aditya; Subaryono; Harintaka

Publication Year: 2020 , Page(s): 604 - 608

Abstract $(578 \mathrm{~Kb})$

$\square \quad$ Comparison of the Latest DTM with DEM Pleiades in Monitoring the Dynamic Peatland

Atriyon Julzarika; Trias Aditya; Subaryono; Harintaka

2020 3rd International Seminar on Research of Information Technology and Intelligent Systems (ISRITI)

Year: 2020

Predicting User Preferences with XGBoost Learning to Rank Method

Nunung Nurul Qomariyah; Dimitar Kazakov; Ahmad Nurul Fajar

Publication Year: 2020 , Page(s): 123 - 128

Abstract (739 Kb)

Predicting User Preferences with XGBoost Learning to Rank

Method

Nunung Nurul Qomariyah; Dimitar Kazakov; Ahmad Nurul Fajar

2020 3rd International Seminar on Research of Information Technology and

Intelligent Systems (ISRITI)

Year: 2020

Performance Analysis of Temporally Ordered Routing Algorithm Protocol and Zone Routing Protocol on Vehicular Ad-Hoc Network in Urban Environment

Heru Nurwarsito; M Yanuar Umam

Publication Year: 2020 , Page(s): 176 - 181

Abstract (790 Kb)

Performance Analysis of Temporally Ordered Routing Algorithm

Protocol and Zone Routing Protocol on Vehicular Ad-Hoc

Network in Urban Environment

Heru Nurwarsito; M Yanuar Umam

2020 3rd International Seminar on Research of Information Technology and Intelligent Systems (ISRITI)

Year: 2020

DDoS Attack Detection in Software Defined Network using Ensemble Kmeans++ and Random Forest

Diash Firdaus; Rendy Munadi; Yudha Purwanto

Publication Year: 2020 , Page(s): 164 - 169

Abstract (382 Kb)

DDoS Attack Detection in Software Defined Network using

Ensemble K-means++ and Random Forest

Diash Firdaus; Rendy Munadi; Yudha Purwanto

2020 3rd International Seminar on Research of Information Technology and Intelligent Systems (ISRITI)

Year: 2020

Hybrid Method for Flower Classification in High Intra-class Variation

Faisal Ridwan Siregar; Wikky Fawwaz Al Maki

Publication Year: 2020 , Page(s): 73 - 78

Abstract $(2038 \mathrm{~Kb})$

Hybrid Method for Flower Classification in High Intra-class

Variation

Faisal Ridwan Siregar; Wikky Fawwaz Al Maki

2020 3rd International Seminar on Research of Information Technology and

Intelligent Systems (ISRITI)

Vaar. onon 
The Best Parameter Tuning on RNN Layers for Indonesian Text Classification Awaliyatul Hikmah; Sumarni Adi; Mulia Sulistiyono

Publication Year: 2020 , Page(s): 94 - 99

Abstract $\quad(772 \mathrm{~Kb})$

The Best Parameter Tuning on RNN Layers for Indonesian Text Classification

Awaliyatul Hikmah; Sumarni Adi; Mulia Sulistiyono

2020 3rd International Seminar on Research of Information Technology and

Intelligent Systems (ISRITI)

Year: 2020

Detection of Sensor Node-less Area Using A Genetic Algorithm for Wireless

Sensor Network

Ferry Wahyu Wibowo; Eko Sediyono; Hindriyanto Dwi Purnomo

Publication Year: 2020 , Page(s): 257 - 261

Abstract $(295 \mathrm{~Kb})$

Detection of Sensor Node-less Area Using A Genetic Algorithm for Wireless Sensor Network

Ferry Wahyu Wibowo; Eko Sediyono; Hindriyanto Dwi Purnomo

2020 3rd International Seminar on Research of Information Technology and

Intelligent Systems (ISRITI)

Year: 2020

Initial Access in 5G mmWave Communication using Hybrid Genetic Algorithm and Particle Swarm Optimization

Muhammad Farras Archi; Dadang Gunawan

Publication Year: 2020 , Page(s): 182 - 186

Abstract (399 Kb)

Initial Access in $5 \mathrm{G}$ mmWave Communication using Hybrid

Genetic Algorithm and Particle Swarm Optimization

Muhammad Farras Archi; Dadang Gunawan

2020 3rd International Seminar on Research of Information Technology and

Intelligent Systems (ISRITI)

Year: 2020

Stemming Javanese: Another Adaptation of the Nazief-Adriani Algorithm Mohammad Arifin Nq; Lindung Parningotan Manik; Dany Widiyatmoko

Publication Year: 2020 , Page(s): 627 - 631

Abstract $\quad(537 \mathrm{~Kb})$

Stemming Javanese: Another Adaptation of the Nazief-Adriani

Algorithm

Mohammad Arifin Nq; Lindung Parningotan Manik; Dany Widiyatmoko

2020 3rd International Seminar on Research of Information Technology and

Intelligent Systems (ISRITI)

Year: 2020

$\square$ Robust Control Design Procedure and Simulation of PRES Controller having

Phase-Locked Loop(PLL) control technique in Grid-Tied Converter

Uma Yadav; Anju Gupta; Rajesh Ahuja

Publication Year: 2020 , Page(s): 445 - 450

Abstract (559 Kb)

Robust Control Design Procedure and Simulation of PRES

Controller having Phase-Locked Loop(PLL) control technique in

Grid-Tied Converter

Uma Yadav; Anju Gupta; Rajesh Ahuja

2020 3rd International Seminar on Research of Information Technology and

Intelligent Systems (ISRITI)

Year: 2020

Leveraging Side Information to Anime Recommender System using Deep learning

Nuurshadieq; Agung Toto Wibowo

Publication Year: 2020 , Page(s): 62 - 67

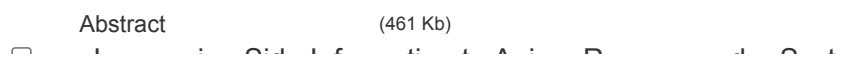


Nuurshadieq; Agung Toto Wibowo

2020 3rd International Seminar on Research of Information Technology and Intelligent Systems (ISRITI)

Year: 2020

$\begin{array}{lll}\text { CHANGE USERNAME/PASSWORD } & \text { PAYMENT OPTIONS } & \text { COMMUNICATIONS PREFERENCES } \\ \text { VIEW PURCHASED DOCUMENTS } & \text { PROFESSION AND EDUCATION } \\ & \text { TECHNICAL INTERESTS }\end{array}$

About IEEE Xplore Contact Us Help Accessibility Terms of Use Nondiscrimination Policy Sitemap Privacy \& Opting Out of Cookies

Purchase Details
»Payment Options
» Order History
„View Purchased Documents

Purchase Details

Profile Information

\Communications Preferences

»Profession and Education

» Technical Interests
US \& CANADA: +18006784333

WORLDWIDE: +17329810060

CONTACT \& SUPPORT
Need Help?

》US \& Canada: +1 8006784333

) Worldwide: +17329810060

"Contact \& Support

About IEEE Xplore Contact Us Help Accessibility Terms of Use Nondiscrimination Policy Sitemap Privacy \& Opting Out of Cookies 


\section{YOGYAKARTA - INDONESIA, 10 DECEMBER 2020}

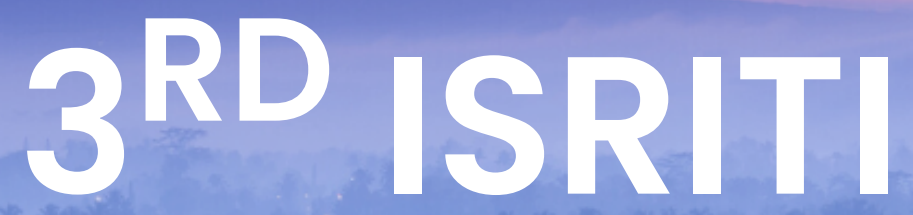

\section{$20203^{\text {RD }}$ INTERNATIONAL SEMINAR ON RESEARCH OF} INFORMATION TECHNOLOGY AND INTELLIGENT SYSTEMS (IEEE CONFERENCE \#51436)



ISRITI Previous Publication : IEEE Xplore \& SCOPUS Indexed

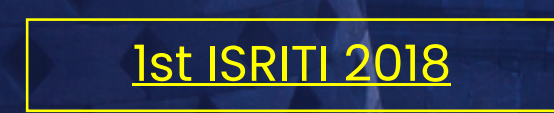
2nd ISRITI 2019

3rd ISRITI 2020 will be conducted as a VIRTUAL conference (online) 10 December 2020 


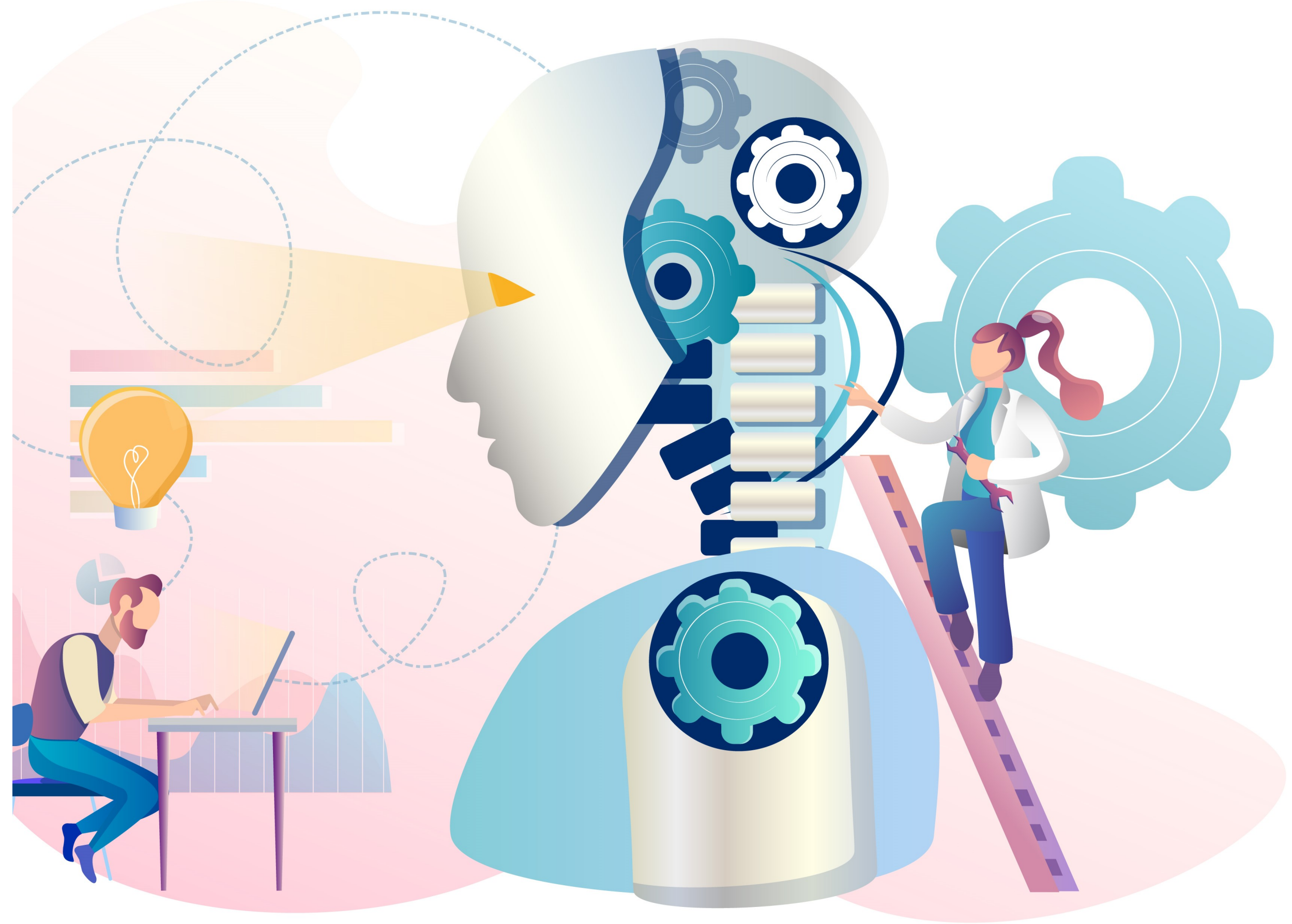

\section{About Event}

We inform you that the STMIK AKAKOM Yogyakarta will organize The $3^{\text {rd }}$ International Seminar on Research of Information Technology and Intelligent Systems 2020 (ISRITI 2020) (http://isriti.akakom.ac.id/). This seminar will take place from 10 December 2020 in Grand Inna Malioboro Hotel, Yogyakarta, Indonesia. This seminar will be connection to the most influential ideas and systems in the field of information technology and intelligent systems. Join us at $3^{\text {rd }}$ ISRITI 2020 and contribute to the research-led exploration and discussion of the current, development, and emerging state of the information technology and intelligent systems.

The purpose of this seminar is to provide a platform for academics, practitioners, researchers, and governments to identify and explore the issues, opportunities, and solutions that promote information technology and intelligent system convergences, developments and find new business, technology, and societal value from the information technology and intelligent systems. 


\section{Call Tor Papers}

We invite submissions in all areas of information technology and intelligent systems research. In particular, we encourage submissions related to the seminar theme :Artificial Intelligence for Social Interactions. We, in the name of the committe, hope you enjoy this seminar and have a great day in Yogyakarta.

All accepted papers must be presented orally (offline) or online in the Conference in order to be published in the proceeding, unless their paper will not be published in the proceeding.

\section{Topics of interest include (but are not limited to):}

\section{Data and Distributed Computing}

1. Big Data

2. Mobile Cloud Services

3. Distributed and collaborative development

4. Intelligent Systems for Cloud and Services Computing

5. Soft Computing, Fuzzy Logic and Artificial Neural Networks

6. Mathematical Modeling and Simulation

$$
\begin{aligned}
& \text { 7. Green Computing } \\
& \text { 8. Cloud Computing }
\end{aligned}
$$

9. Data Mining, Web Technology and Ontology

10. Smart, distributed intelligent factory

11. Decision support systems, performance indicators and control

12. Nanoelectronics and Quantum Computing

13. Decentralized System

\section{Computer Network, Security, Privacy.}

1. Adhoc Networks and Wireless Networks

2. Sensor networks

3. Network design and architecture

4. Advanced network infrastructures and internetworking

5. Security and Authentication

6. RFIDs and Applications

7. Vehicular Technology and Networks

8. Information Security and Network Security

9. Parallel and Distibuted Systems

10. Remote Sensing and Geographic Information System

11. Multimedia Information Processing and Retrieval

12. Telecommunication and Mobile Communication

\section{Smart and Autonomous System}

1. Computer Vision

2. Artificial Intelligence

3. Pattern Recognition

4. Autonomous robotics and transportation

5. Image, Speech, and Signal Processing

6. Nano Technology

7. Grid Technology

8. Power Systems

9. Distributed embedded systems

10. Vehicular Technology

11. Simulation and Hardware Implementation

Techniques

12. Manufacturing systems

13. Robotics and Mecatronics

15. Networked health and medical systems

Internet Services, Application, and Technology.
1. Internet Technologies
2. Internet Architecture
3. Internet of Things (IOT)

4. IoT services and applications

5. Artificial Intelligence and Expert Systems

6. Knowledge Engineering and Management

7. Software-defined Networking

8. Communication Systems and Communication Standards

9. Virtualization 


\section{VIRTUAL CONFERENCE GUIDELINES AND PREPARATION}

As you know, due to the COVID-19 situation, the 2020 3rd ISRITI is using a virtual conference, which will be held via the Zoom/Google Meet event platform. To prepare for the virtual conference, we ask you to submit a pre-recorded presentation (voice-over PowerPoint) in advance.

Each paper will be given 15 minutes ( 10 minutes for presentation +5 minutes for Q\&A). At least one author must join the live virtual session to answer questions. Please carefully review the following guidelines and specifications before recording your presentation.

The deadline for all video submissions is 5 December 2020!

\section{INSTRUCTIONS FOR RECORDING PRESENTATION}

The recording should contain a prominent view of the presentation slides along with audio of the presenter. The recording may also contain a small headshot of the presenter. Many presentation software allows recording audio and video directly in the application and can export appropriate video files.

The presentation recording should:

1. Be 10-minute in length

2. Set for HD format ( $1280 \times 720$ or other "720p" setting)

3. Use simple (Arial, Calibri) and large (30+) fonts

4. Avoid using hi-res images

5. Have NO embedded videos

6. Saved as MPEG-4 (.mp4) file using the session ID and last name as the file name. For example "IA_Nugroho"

For more information on how to pre-record your presentation, please look at this below.

\section{POWERPOINT}

Follow these instructions to add audio (and optionally video) to your slides.

Follow these instructions to generate a MPEG-4 (.mp4) file from your slides and audio/video.

Alternatively, you can follow this video tutorial which goes through both of these steps. Also, see this video tutorial if you like.

\section{OTHER OPTIONS}

Record your screen (and microphone) while giving the presentation. There are effective and free options to do this on Linux, macOS, and Windows. As a last resort, and only if you are comfortable directly editing video, you can export your slides as images, record an audio track, and combine the two using software like kdenlive, iMovie, or others. Please be sure to review your recorded presentation prior to submission. Once you are happy with the final product, then please upload it to Google Drive.

The deadline to submit your recording presentation is 5 December 2020 


\section{Speakers}



Dr. Zoohan Gani

Victoria University, Sydney Australia

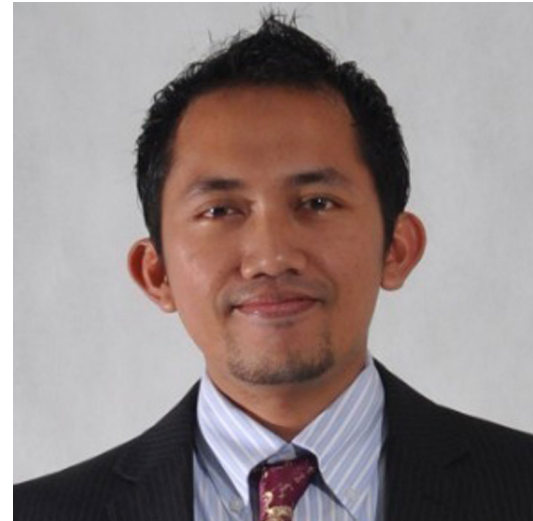

Assoc.Prof.Dr. Ahmad Hoirul Basori

King Abdulaziz University, Rabigh, Makkah Saudi Arabia

\section{Submission}

Submission Type: Full Paper

\section{Important Dates}

Early Bird

Paper Submission: $\mathbf{3 1}$ July $\mathbf{2 0 2 0}$

Notification of Acceptance : HAugust 2020

Registration : 17 August 2020

Final Paper Submission : 24 August 2020

\section{Reguler}

Full Paper Submission : 100etober 2020

Notification of Acceptance : 15 November 2020

Registration : 25 November 2020

Final Paper Submission : 25November 2020

\section{CONFERENCE DATE : 10 DECEMBER 2020}

Authors are invited to submit Paper must be using IEEE Paper format, to download IEEE Paper format template: IEEE Conference Template Doc or latex template

ONLINE SUBMISSION via EDAS

ED

AS 


\section{Using PDF EXPRESS}

\section{Why you need to use PDF eXpress:}

The new IEEE Xplore ${ }^{\circledR}$ Requirements for PDF will be enforced as of 2005. All conference articles submitted to IEEE sponsored conferences must be in IEEE Xplore-compatible PDF format.

IEEE offers PDF eXpress as a free service to IEEE conference authors, allowing you to make Xplore-compatible PDFs (Conversion function) or to check PDFs you have created yourself for Xplore compatibility (PDF Check function).

\section{Advantages to authors:}

1. It provides a means for you to convert your files to PDF, without requiring you to have access to a conversion program. 2. This conversion is provided in an IEEE Xplore compatible format, without you having to worry about conversion settings.

3. The system emails the converted file back to you, so you can make sure that your contribution is IEEE Xplore compatible and that no unintended corruption occurred.

4. It ensures that your paper views and prints as well as possible in IEEE Xplore.

5. By minimizing the risk of post-processing problems, it reduces the amount of time it will take for your paper to appear on IEEE Xplore.

6. It greatly simplifies the task of conforming to IEEE submission requirements.

Steps for creating your Xplore compliant PDF file:

1. Create your manuscript

2. Proofread and check layout of manuscript. (It is highly recommended that you do this BEFORE going to PDF eXpress.)

3. Create PDF eXpress account

4. Upload source file(s) for Conversion; and/or PDF(s) for Checking

5. Use PDF eXpress to attain Xplore-compatible PDFs. The site contains extensive instructions, resources, and helpful hints.

6. IMPORTANT: After finishing with the PDF eXpress web site, return to the website below to submit your final, Xplorecompatible PDF(s) on the IEEE ISRITI 2020 Submission site at https://edas.info/N27708.

\section{Using PDF eXpress:}

1. Click link or PDF eXpress logo (at top of page) to go to the PDF eXpress web site.

2. Once at the PDF express web site, create a new account by clicking on "New Users - Click Here" link.

3. Enter 51436X for the Conference ID

4. Continue to enter information as prompted. You will receive an email confirming the successful creation of your account.

5. Through your PDF eXpress account, you may submit your source application files for conversion to PDF, and/or submit PDFs for checking. You will have the opportunity to revise your submission if you are not satisfied with the PDF that PDF eXpress creates for you, if you find mistakes in your manuscript, or if your PDF fails the PDF Check.

6. Technical support via email is available if you experience trouble in creating your PDF: pdfsupport@ieee.org 


\section{Registration}

\section{PAYMENT METHOD}

Online registration along with the receipt of transferred fee, as an attachment Registration will be confirmed only when the registration fee (non-refundable) has been paid.

For local participants can pay via bank transfer, information below.

BANK BNI, an. SUMIYATUN.

No Rekening. 0272178346

Online Registration via EDAS

ED

AS

Registration MUST be done after your paper is accepted and before uploaded the final manuscript (camera ready). Here are the registration fee

INTERNATIONAL PARTICIPANT IOCAL PARTICIPANT

CATEGORIES

EARLY BIRD

REGULAR

EARLY BIRD

REGULAR

IEEE Students*

$\$ 150$

$\$ 175$

IDR 1,500,000

IDR 1,750,000

Regular Students (Non IEEE)

$\$ 175$

$\$ 225$

IDR $1,750,000$

IDR 2,250,000

IEEE Profesiona

$\$ 175$

$\$ 225$

IDR $1,750,000$

IDR 2,250,000

Regular Profesional (Non IEEE)

$\$ 200$

$\$ 225$

IDR 2,000,000

IDR 2,250,000

Conference Attendee

$\$ 25$

$\$ 50$

IDR 250,000

IDR 500,000

Extra Paper (per paper)

$\$ 125$

$\$ 150$

IDR $1,250,000$

IDR 1,500,000

Extra Page (per page)

$\$ 25$

$\$ 50$

IDR 250,000

IDR 500,000

* Three foreign IEEE student travel grants are provided (term and condition applied).

Please send your ID card when registration

\section{CANCELLATION POLICY}

All refund/cancellation requests must be provided via email to isriti@akakom.ac.id (Subject: Cancellation ISRITI 2020) and received by 1 December 2020.

No refunds will be provided after this date. There will be an IDR 800,000 administrative fee deducted from each refund. Please note that author and/or additional paper registrations are non-refundable.

\section{VISA INFORMATION}

In accordance with the Regulation of Minister of Law and Human Right of the Republic of Indonesia Number 26, 2013, citizen from 61 countries and 1 region are eligible for obtaining Visa on Arrival (VOA). This visa can be obtained directly when you are landed at the certain airports and seaport in Indonesia regardless of the purpose of your visits (Business, Tourist, Social). The Visa on Arrival is not a work visa nor a visitation visa. Therefore, it can not be converted to obtain other immigration permits. The maximum stays permitted for the visa on arrival is 30 days. If you plan to stay longer than 30 days, you need to mention your intention to stay longer. Visa on Arrival can be extended for another 30 days. 
The fees for Visa On Arrival are:

- Visa for stay up to 7 (seven) days in several Special Economic Zones (SEZ)= US\$ 15,-

- Visa for stay up to 30 (thirty) days = US\$ 35,-

- Extension of stay for up to 30 (thirty) days = US\$ 35,-

\section{Committee}

Steering Committee:

Prof. Chuan-Ming Liu, Ph.D (National Taipei University of Technology, Taiwan)

Dr. Widyastuti Andriyani, M.Kom. (STMIK AKAKOM)

Totok Suprawoto,M.M., M.T. (STMIK AKAKOM)

Organizing Committee:

Dr. Bambang Purnomosidi Dwi Putranto, S.E., Ak., S. Kom., MMSI (General Chair)

Maria Mediatrix, S.Kom., M.Eng. (Co-Chair)

Edy Prayitno, S.Kom., M.Eng.(Secretary)

Sumiyatun, S.Kom., M.Cs.(Treasury)

Assoc. Prof. Dr. Setyawan Widyarto, M.Sc. - University of Selangor, Malaysia (Publication Chair)

Domy Kristomo, S.T., M.T. (Chair of TPC)

Technical Committee :

M. Agung Nugroho, M.Kom.

Luthfan Hadi Pramono, S.ST., M.T.

Ariesta Damayanti, S.Kom., M.Cs.

Robby Cokro Buwono, S.Kom., M.Kom.

Ir. M Guntara, M.T.

Agung Budi Prasetyo, S.Kom., M.Kom.

\section{Technical Program Committee :}

Dr. Intan Ermahani A. Jalil (Universiti Teknikal Malaysia Melaka)

Dr. Rusli Abdullah (Universiti Putra Malaysia)

Dr. Tapodhir Acharjee (Assam University, Silchar)

Mr. Syed Ahmed (NED University of Engineering and Technology)

Dr. Michele Albano (Aalborg University)

Dr. Baba Alhaji (Nigerian Defence Academy)

Mr. Eko Aribowo (Ahmad Dahlan University)

Dr. Ahmad Ashari (Gadjah Mada University)

Mr. Azizul Azizan (Universiti Teknologi Malaysia (UTM))

Dr. Aslina Baharum (Universiti Malaysia Sabah)

Dr. Maria Chiara Caschera (CNR)

Dr. Wichian Chutimaskul (King Mongkut's University of Technology Thonburi)

Mr. Andi Wahju Rahardjo Emanuel (Universitas Atma Jaya Yogyakarta)

Dr. Ahmad Fajar (Bina Nusantara University) 
Dr. Ridi Ferdiana (Universitas Gadjah Mada)

Dr. Dhomas Hatta Fudholi (Universitas Islam Indonesia)

Mr. Alireza Ghasempour (ICT Faculty)

Dr. Razvan Andrei Gheorghiu (Politehnica University of Bucharest)

Prof. Paulo Gil (Universidade Nova de Lisboa)

Mr. Rifqy Hakimi (ITB)

Mr. Byeong-jun Han (Soongsil University)

Mr. Seng Hansun (Universitas Multimedia Nusantara)

Dr. Su-Cheng Haw (MMU)

Mr. Leonel Hernandez (ITSA University)

Mr. Roberto Carlos Herrera Lara (National Polytechnic School)

Dr. Danial Hooshyar (Korea University)

Dr. Paramate Horkaew (Suranaree University of Technology)

Mrs. Noor Aida Husaini (Universiti Tun Hussein Onn Malaysia)

Dr. Muhamad Syamsu lqbal (University of Mataram)

Dr. Nurulisma Ismail (Universiti Malaysia Perlis)

Mr. Ramkumar Jaganathan (VLB Janakiammal College of Arts and Science)

Prof. Dimitrios Kallergis (University of West Attica)

Mrs. Kartika Kirana (Universitas Negeri Malang)

Dr. Pavel Loskot (Swansea University)

Mr. Sanoop Mallissery (National Chiao Tung University)

Dr. Kishore Manjanna (VTU)

Dr. Sukrisno Mardiyanto (Institut Teknologi Bandung)

Mrs. Prita Dewi Mariyam (Universitas Indonesia)

Dr. Miftahuddin Miftahuddin (Syiah Kuala University)

Dr. Ahmed Mobashsher (The University of Queensland)

Mrs. Haslizatul Mohamed Hanum (Universiti Teknologi MARA)

Dr. Seyed Sahand Mohammadi Ziabari (Vrije University of Amsterdam)

Prof. Philip Moore (Lanzhou University)

Prof. Muhammed Bashir Mu'azu (Ahmadu Bello University, Zaria)

Dr. Amrit Mukherjee (Jiangsu University)

Mr. Rinaldi Munir (Institut Teknologi Bandung)

Mr. Shah Nazir (University of Peshawar)

Dr. Hu Ng (Multimedia University)

Dr. Kok-Why Ng (Multimedia University)

Dr. Ruzelita Ngadiran (Universiti Malaysia Perlis)

Dr. Zarina Mohd Noh (Universiti Teknikal Malaysia Melaka)

Dr. Hanung Nugroho (Universitas Gadjah Mada)

Dr. Ilker Ali Ozkan (Selcuk University)

Mr. Gede Pramudya Ananta (Universiti Teknikal Malaysia Melaka)

Mr. Melky Radja (Universitas Atma Jaya Yogyakarta)

Mr. Rasim Rasim (Indonesia University of Education)

Mr. Bagus Rintyarna (Sepuluh Nopember Institute of Technology)

Dr. Dedi Rohendi (Universitas Pendidikan Indonesia)

Dr. Houari Sabirin (KDDI Research, Inc.)

Abdulraqeb Alhammadi, Ph.D (Multimedia University, Malaysia) 


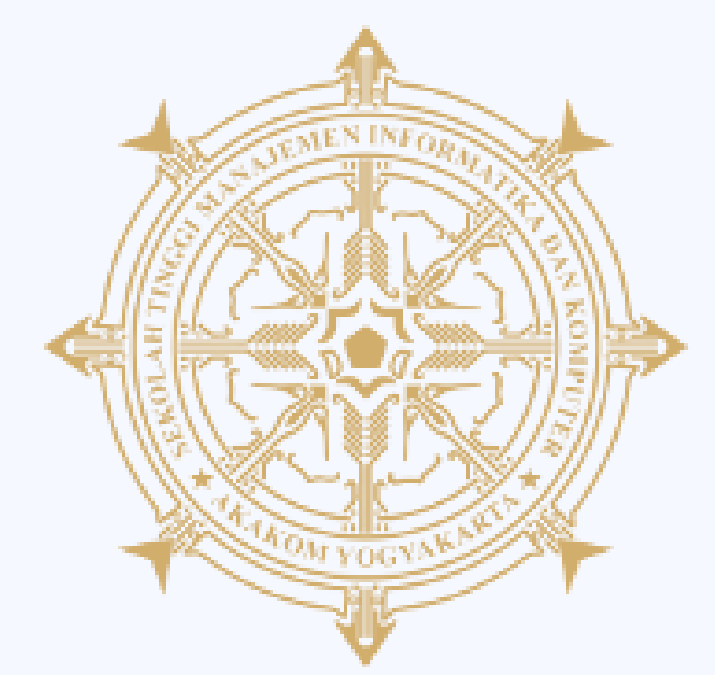
STMIK AKAKOM
Y O G Y A K A R T A Code for life

\section{Technical Support Sponsors}


\section{INDONESIA SECTION}

\section{Get In Touch}

Email address

isriti@akakom.ac.id

Phone Number

+62 858-4813-5411 (whatsapp only) 


\section{Venue Location}

\section{Grand Inna Malioboro Hotel}

JI. Malioboro No.60, Suryatmajan, Kec. Danurejan, Kota Yogyakarta, Daerah Istimewa Yogyakarta 55213.

\section{Grand Inna Malioboro}

JI. Malioboro No.60, Suryatmajan,

Kec. Danurejan, Kota Yogyakarta,

Daerah Istimewa Yogyakarta 55213

4,5

14.073 ulasan

Lihat peta lebih besar

\section{(14)} Rute

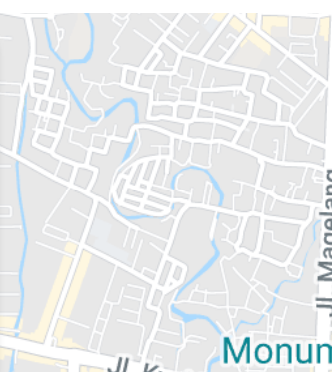

Jl. Kyai Mojo
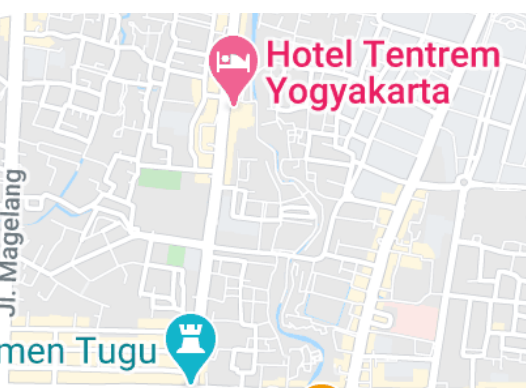

(41) The House Of Raminten

$$
\text { KP. KLITREN }
$$

Grand Inna Malioboro

Abadi Malioboro Jogja

by Tritama Hospitality

Hotel kasual dengan spa \& 3 restoran

\section{Pabrik Bakpia Pathok 25}

(마) Grand Malioboro

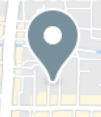

Titik Nol Kilometer Jogja

Keraton Yogyakarta?

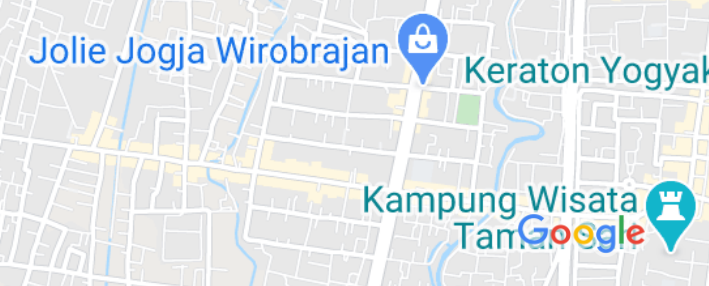

\section{- Jambuluwuk \\ Malioboro Hotel \\ Hatel kosmopolitan}

J. Sultan Agung
3
0

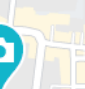

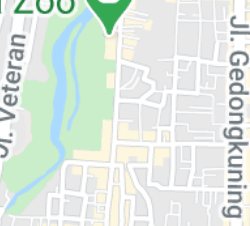

Data peta @2021 Google 


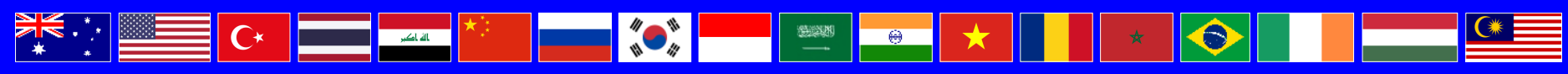

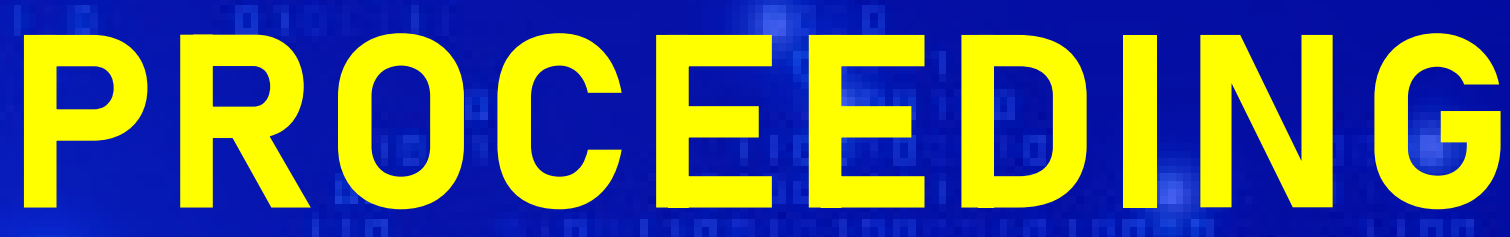

\section{\#3rd}



Yogyakarta - Indonesia 10 December 2020

\section{ARTIFICIAL INTELLIGENCE for SOCIAL INTERACTIONS}

isriti.akakom.ac.id

STMIK AKAKOM Y O G Y A K A R T A
- IEEE

全IEEE 
$20203^{\text {rd }}$ International Seminar on Research of Information Technology and Intelligent Systems (ISRITI) took place 10 December 2020 in Yogyakarta, Indonesia

$\begin{array}{ll}\text { IEEE catalog number: } & \text { CFP20AAH-ART } \\ \text { ISBN: } & 978-1-7281-8406-7\end{array}$

Copyright and Reprint Permission: Abstracting is permitted with credit to the source. Libraries are permitted to photocopy beyond the limit of U.S. copyright law for private use of patrons those articles in this volume that carry a code at the bottom of the first page, provided the per-copy fee indicated in the code is paid through Copyright Clearance Center, 222 Rosewood Drive, Danvers, MA 01923. For other copying, reprint or republication permission, write to IEEE Copyrights Manager, IEEE Operations Center, 445 Hoes Lane, Piscataway, NJ 08854. All rights reserved. Copyright (C) 2020 by IEEE. 


\section{International Seminar on Research of Information Technology and Intelligent Systems}

\section{The $3^{\text {rd }}$ ISRITI 2020}

10 December 2020

STMIK AKAKOM YOGYAKARTA

Jalan Raya Janti no 143, Karang Jambe, Banguntapan, Bantul Yogyakarta, Indonesia 55198

Phone: +ㅁ2 858-4813-5411 (whatsapp only) | Email: isriti@akakom.ac.id

www.isriti.akakom.ac.id 


\title{
WELCOME SPEECH FROM THE CHAIRMAN OF STMIK AKAKOM YOGYAKARTA
}

\author{
The honourable \\ Keynote Speakers (Dr. Zoohan Gani from Victoria University and Assc. Prof. Ahmad \\ Hoirul Basory from King Abdul Azis University) \\ Chairman of Widya Bakti Foundation and his staffs, \\ Representatives from IEEE Indonesia Chapter and Central IEEE, \\ Team of Indonesia Researcher and Scientist Institute, \\ Researchers and conference attendees, \\ Ladies and Gentlemen,
}

Assalamu'alaikum $W r$. Wb.

May peace and health be upon us all.

First of all, let us express our utmost gratitude to God Almighty (SWT) for His blessings and grace so that even though in this coronavirus pandemic atmosphere, we can all still participate in the third iSriti international conference. On this occasion, let me express my sincere appreciation to the Keynote Speakers: Dr. Zoohan Gani from Victoria University, Sydney Australia, and Assoc. Prof. Dr. Ahmad Hoirul Basory from King Abdul Azis University, Rabig, Makkah, Saudi Arabia for their willingness to share their brilliant ideas and insights to be presented at this conference.

Dear ladies and gentlemen

On this occasion, as the head of STMIK AKAKOM Yogyakarta, I am saddened to state that the third iSriti conference had to be held online, considering that the coronavirus pandemic has not ended. Even though a pandemic currently hits us, the researchers' enthusiasm is apparent in the number of research articles submitted. We received up to 262 articles from 17 countries. Around 135 articles were accepted to be readily presented online in a conference forum with the theme: Artificial Intelligence for Social Interactions.

As the organizers of iSriti, we are very proud and grateful for the researchers' participation who have been willing to submit their research results to be published in this conference forum. We would also like to thank IEEE and IRSI, who have trusted and supported this conference from the very beginning. We still hope to build networks and information exchange between academics, practitioners, researchers, and the government to identify and explore issues, opportunities, and solutions to face challenges in the current era of technological disruption.

Finally, on this occasion, I would like to express my utmost gratitude to:

1) The distinguished keynote speakers who have been willing to share their valuable knowledge in this conference;

2) The third iSriti researchers who have presented and will present their research results;

3) Reviewers who have carefully reviewed the articles of the researchers;

4) Moderators who are more than willing to lead the plenary session;

5) IEEE for trusting us to hold this international conference;

6) IRSI, which has supported the third iSriti activities until now;

7) The committee that has been working hard to prepare this international conference according to plan; Last but not least, as the organizer, I would like to sincerely apologize for any shortcomings or inconveniences during this event.

Thank you very much for your kind attention, and Wassalamu'alaium $W r . W b$.

Yogyakarta, 10 December 2020

The Chairman of STMIK AKAKOM Yogyakarta

Totok Suprawoto, M.M., M.T. 


\section{WELCOME SPEECH FROM THE GENERAL CHAIR OF THE $3^{\text {rd }}$ ISRITI 2020}

Dear colleagues and friends.

On behalf of the organizing committee, I am delighted to welcome all participants to the 3rd International Seminar on Research of Information Technology and Intelligent Systems (ISRITI 2020). This conference is the third international conference held by STMIK Akakom Yogyakarta, Indonesia and the first to be held by STMIK Akakom in virtual form on December 10th, 2020.

In this conference, the committee decided to choose the following theme: "Artificial Intelligence for Social Interactions". This highlight was chosen because various advances in the field of AI have recently raised concerns that AI will replace various things that are the human domain. For us, AI can be used to better understand social interactions and to build machines that work more collaboratively and effectively with humans. Therefore, by highlighting that theme in ISRITI 2020, we hope we can raise awareness towards AI for social interactions.

The aim of the conference is to provide an interactive international forum for sharing and exchanging information on the latest research in the area of information technology, computer sciences, informatics, and related fields. Nearly 135 academicians, researchers, practitioners, and presenters from 17 countries (Indonesia, Malaysia, India, USA, Brazil, Australia, South Korea, Hungary, Morocco, Vietnam, Iraq, China, Thailand, Turkey, Ireland, Romania, Russia, and Saudi Arabia) gathered in this event. In total, there are 262 active papers submitted to this conference. Each paper has been reviewed with tight criteria from our invited reviewers. Based on the review result, 135 papers have been accepted, which lead to an acceptance rate of $51.5 \%$. This conference will not be successful without extensive effort from many parties. First, I would like to thank all keynote speakers for allocating their valuable time to share their knowledge with us. I would also like to express my sincere gratitude to all participants who participate in this conference. Special acknowledgement should go to the Technical Program Committee Chairs, Members, and Reviewers for their thorough and timely reviewing of the papers. We would also like to thank our sponsors: IEEE Indonesia Section and Research and Society Service Institution at STMIK Akakom. Last but not least, recognition should also go to the Local Organizing Committee members who have put enormous effort and support for this conference. At last, we hope that you have an enjoyable and inspiring moment during our conference. Thank you for your participation in ISRITI 2020.

Yogyakarta, 10 December 2020

General Chair of the 3rd ISRITI 2020

\section{Dr. Bambang Purnomosidi D. P.}




\title{
PREFACE
}

A language and reasoning can be said as some of the characteristics of human abilities. On the other hand, the ability of human thinking can be modeled as computation. The development of cognitive science that combines scientific development with technology began to appear in the 1960s. In those years, human behavior did not adequately explain cognitive processes. Although, there has been much debate by behaviorist experts regarding the cognitive science approach. However, with a variety of approaches, there is something quite encouraging that computer models of cognition can be used as an alternative approach to these various models. Furthermore, computers can be used to test hypotheses where computation itself is the subject of the mind. So that there are various kinds of models developed in the field of cognitive science with different fields of science, including anthropology, artificial intelligence (AI), philosophy, linguistics, neuroscience, and psychology. Even though there are different scientific fields, it turns out that they can work together in explaining various kinds of cognitive science models. AI is a part of the field of computer science that can describe intelligent computer systems. This system can show characteristics related to intelligence in human behavior, such as reasoning, understanding language, learning, solving problems, and so on. This intelligent system has a long-term goal of equaling or surpassing human intelligence. The approach used in simulating this system uses mathematical approaches, discursive reasoning, language, and so on. New developments related to the paradigm in this field emerged in the mid-80s, bringing together developments in the fields of philosophy, AI, and cognitive science.

Human intelligence is illustrated as a result of a program running on the human brain. In connectionist's view, information processing on computer devices is a fundamental difference from the brain. In the contextsensitive cognition model, human intelligence depends on the physical properties of the neurons. So that artificial intelligence requires brain-like computer skills, better known as neurocomputers. The purpose of this terminology is to design hardware compatible with neuro-computing. In this case, the model that is later known massively is an artificial neural network in which this model is trained, not programmed. Much information is extracted deeper than a representation that is presented in various forms that can be understood by humans. In the past, artificial emotions were somewhat neglected in AI and cognitive science. However, currently, emotional intelligence is one of the things that is raised with relevant information indicators in solving a case or problem. Emotion has an important domain in motivating and directing behavior. So that discussions in cognitive science and AI become one of the raw materials in representing information, then use it in social interactions. This representation is a language capable of thinking about problem-solving and social processes. This explains the systematics or methods used are very important in understanding cognition and communication in the context of social interaction. This pattern has appeared in the childhood phase in the learning process until later understanding their identity and interacting with others in the form of communication. The basis for this transformation is then essential in solving many cases in the world of science and technology.

\section{Editor of 2020 3rd ISRITI}

\author{
Ferry Wahyu Wibowo \\ ORCID ID: 0000-0003-1913-436X
}




\section{Host}

STMIK AKAKOM Yogyakarta

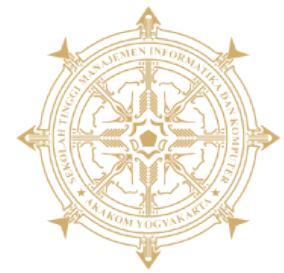

STMIK AKAKOM code for life

\section{Technical Support}

IEEE Indonesia Section

$$
\text { (4) IEEE }
$$




\title{
Some Numerical and Analytical Solutions to an Enzyme-Substrate Reaction-Diffusion Problem
}

\author{
Sudi Mungkasi \\ Department of Mathematics, Faculty of Science and Technology, \\ Sanata Dharma University \\ Yogyakarta, Indonesia \\ sudi@usd.ac.id
}

\begin{abstract}
We consider an enzyme-substrate reactiondiffusion problem. Unsteady and steady state models are recalled. For the unsteady state case, the model is in the form of a second order partial differential equation. We solve the unsteady state model using the explicit numerical finite difference method, which is forward difference in time and centered difference in space. For the general steady state case, the model is in the form of a second order ordinary differential equation. We solve the general steady state model using the explicit first order Euler's numerical method. For the particular steady state case of the unsaturated catalytic kinetics, we derive the exact analytical solution using the characteristic method of ordinary differential equations. For the particular steady state case of the saturated catalytic kinetics, we derive the exact analytical solution using the direct-integration method. The obtained exact analytical solutions are identical with the existing exact analytical solutions derived using the variational iteration method. With the aid of computer, the enzyme-substrate reaction-diffusion problem can be solved and simulated successfully for both unsteady and steady state cases.
\end{abstract}

Index Terms-enzyme-substrate system, finite difference method, reaction-diffusion problem, saturated steady state, unsaturated steady state

\section{INTRODUCTION}

Chemical reaction problems may incorporate diffusion This process is then called a reaction-diffusion problem. The reaction-diffusion process has been modelled into a mathematical equation. The derivation involves the so called Michaelis-Menten kinetics. The Michaelis-Menten kinetics itself has been widely recognised in chemistry for reaction problems [1, 2, 3, 4, 5, 6, 7].

A number of authors provide some studies of reactiondiffusion in chemical reaction problems. Lyons et al. [8, 9] derived a dimensionless model of the problem, where the system was a boundary value problem. The model of Lyons et al. [8, 9] was then studied by Rahamathunissa and Rajendran [10], where the system was changed to an initial value problem. Furthermore, Mahalakshmi and Hariharan [11] provide an approximation method for solving the initial value problem that was considered by Rahamathunissa and Rajendran [10]. The unsaturated and saturated steady state solutions to the initial value problem have been obtained by Rahamathunissa and Rajendran [10] using a variational iteration method. The variational iteration method was due to $\mathrm{He}[12,13,14]$ and it has been successfully used to solve various problems $[15,16,17,18,19,20,21,22,23,24]$ including the mathematical chemistry areas $[25,26,27,28,29,30]$.

In this paper, we provide an alternative method to solve unsaturated and saturated steady state problems. We implement the characteristic and direct-integration methods for ordinary differential equations in solving the unsaturated and saturated steady state problems. We also provide the unstability property of the equilibrium solution. In addition, finite difference methods for solving the unsteady and steady state problems are provided. Finite difference method has been shown to be powerful for solving various problems [31, $32,33,34,35]$, which also include mathematical chemistry areas [36, 37, 38, 39, 40, 41, 42, 43, 44, 45].

This paper is simply organised as follows: we recall the mathematical models and provide their analytical properties; then, numerical finite difference methods are presented; afterwards, numerical results and discussion are provided; and finally, some concluding remarks are written.

\section{Mathematical Models And Their Properties}

Enzyme-substrate reaction-diffusion models have been derived by Lyons et al. [8]. In this section, we recall the models of unsteady and steady state cases.

\section{A. Unsteady state model}

We consider the following unsteady state dimensionless model

$$
\frac{\partial u(x, t)}{\partial t}=\frac{\partial^{2} u(x, t)}{\partial x^{2}}-\frac{\gamma u(x, t)}{1+\alpha u(x, t)}
$$

with initial condition

$$
u(x, 0)=0,
$$

and boundary conditions

$$
\frac{\partial u(0, t)}{\partial x}=0, \quad u(1, t)=1 .
$$

Here the space domain is $0 \leq x \leq 1$, the time domain is $t \geq 0$, and $u(x, t)$ represents the concentration of substrate at any position $x$ at any time $t$. In addition, parameters $\alpha$ and $\gamma$ are positive constants relating to the reaction process (see $[8,9,10,11]$ for details).

\section{B. Steady state model}

For the steady state condition, time $t$ does not influence the dynamics of the system. Therefore, the steady state model is the following ordinary differential equation

$$
\frac{d^{2} u(x)}{d x^{2}}-\frac{\gamma u(x)}{1+\alpha u(x)}=0 .
$$

Let us consider the function

$$
f(u)=-\frac{\gamma u}{1+\alpha u} .
$$

This function $f$ is zero if and only if $u=0$. This $u=0$ is the equilibrium solution. As

$$
f^{\prime}(u)=-\frac{\gamma}{(1+\alpha u)^{2}},
$$


we obtain $f^{\prime}(0)=-\gamma$, which is a negative value. Here $f^{\prime}(u)=d f(u) / d u$. Based on the theory of linear stability of equilibrium points [46], we infer that the equilibrium solution $u=0$ is unstable. It means that any perturbation of the solution to the equilibrium solution $u=0$ moves away (gets larger in amplitude) from this equilibrium.

1) Unsaturated catalytic kinetics: The unsaturated catalytic kinetics is achieved when $\alpha u<<1$. In this case, equation (4) can be reduced to

$$
\frac{d^{2} u(x)}{d x^{2}}-\gamma u(x, t)=0 .
$$

Here, we shall provide our contribution in providing the exact solution to equation (7) with boundary conditions

$$
u^{\prime}(0)=0, \quad u(1)=1
$$

We derive the exact solution using the characteristic method of ordinary differential equation, as follows. Let us denote that $\lambda$ is the characteristic variable. Then, the characteristic equation for equation (7) is

$$
\lambda^{2}-\gamma=0
$$

The caracteristic roots of equation (9) is $\lambda_{1}=\sqrt{\gamma}$ and $\lambda_{2}=$ $-\sqrt{\gamma}$. The general solution to equation (7) is

$$
u(x)=c_{1} \exp (\sqrt{\gamma} x)+c_{2} \exp (-\sqrt{\gamma} x)
$$

where $c_{1}$ and $c_{2}$ are constants. Incorporating boundary conditions (8) to general solution (10), we obtain that

$$
c_{1}=c_{2}=\frac{1}{\exp (\sqrt{\gamma})+\exp (-\sqrt{\gamma})} .
$$

Therefore, the exact solution to equation (7) with boundary conditions (8) is

$$
u(x)=\frac{\exp (\sqrt{\gamma} x)+\exp (-\sqrt{\gamma} x)}{\exp (\sqrt{\gamma})+\exp (-\sqrt{\gamma})} .
$$

We note that Rahamathunissa and Rajendran [10] used variational iteration method to obtain the exact solution to equation (7) with initial conditions

$$
u(0)=a, \quad u^{\prime}(0)=0,
$$

where $u^{\prime}(x)=d u(x) / d x$. The exact solution to equation (7) with initial conditions (13) is [10]

$$
u(x)=a \cosh (\sqrt{\gamma} x)
$$

Here, we shall also provide an alternative derivation of the exact solution to equation (7) with initial conditions (13) using the characteristic method of ordinary differential equation, as follows. Knowing the general solution to equation (7) is given by equation (10), we incorporate initial conditions (13) to it. Then, we obtain

$$
c_{1}=c_{2}=\frac{a}{2} \text {. }
$$

Therefore, the exact solution to equation (7) with initial conditions (13) is

$$
u(x)=\frac{a}{2}(\exp (\sqrt{\gamma} x)+\exp (-\sqrt{\gamma} x)) .
$$

Function (16) is identical with function (14).
2) Saturated catalytic kinetics: The saturated catalytic kinetics is achieved when $\alpha u>>1$. In this case, equation (4) can be reduced to

$$
\frac{d^{2} u(x)}{d x^{2}}-\frac{\gamma}{\alpha}=0
$$

Here, we shall provide our contribution in providing the exact solution to equation (17) with boundary conditions (8). Integrating (17) twice with respect to $x$, we obtain that the general solution to equation (17) is

$$
u(x)=\frac{\gamma}{2 \alpha} x^{2}+c_{1} x+c_{2},
$$

where $c_{1}$ and $c_{2}$ are constants. Incorporating boundary conditions (8) with equation (17), we obtain

$$
c_{1}=0, \quad c_{2}=1-\frac{\gamma}{2 \alpha} .
$$

Therefore, the exact solution to equation (17) with boundary conditions (8) is

$$
u(x)=\frac{\gamma}{2 \alpha} x^{2}+1-\frac{\gamma}{2 \alpha} .
$$

Rahamathunissa and Rajendran [10] used variational iteration method to obtain the exact solution to equation (17) with initial conditions (13), and obtained that it is

$$
u(x)=a+\frac{\gamma}{2 \alpha} x^{2} .
$$

Here, we provide an alternative derivation of exact solution (21), as follows. Recall that if we integrate (17) twice with respect to $x$, we obtain (18) where $c_{1}$ and $c_{2}$ are constants. Incorporating initial conditions (13) with equation (18), we obtain

$$
c_{1}=0, \quad c_{2}=a .
$$

Then, the exact solution to equation (17) with initial conditions (13) is

$$
u(x)=\frac{\gamma}{2 \alpha} x^{2}+a,
$$

which is identical with function (21).

\section{NUMERICAL METHODS}

Suppose that we are given a closed domain, where $x \in$ $[0,1]$ and $t \in\left[0, t_{f}\right]$, in which $t_{f}>0$ is the final time. We take discrete points $\left\{x_{0}=0, x_{1}, x_{2}, \ldots, x_{M}=1\right\}$ of space and $\left\{t^{0}=0, t^{1}, t^{2}, \ldots, t^{N}=t_{f}\right\}$ of time. Here $\Delta x=x_{m}-x_{m-1}$ for $m=1,2,3, \ldots, M$, and $x_{m}=m \Delta x$ for $m=0$, $1,2, \ldots, M$; in addition, $\Delta t=t^{n}-t^{n-1}$ for $n=1,2,3$ $\ldots, N$, and $t^{n}=n \Delta t$ for $n=0,1,2, \ldots, N$. We denote $u_{m}^{n} \approx u\left(x_{m}, t^{n}\right)$.

\section{A. Finite difference method for the unsteady state model}

A semi-discrete finite difference scheme for solving the unsteady state model (1) is

$$
\frac{d u_{m}}{d t}=\frac{u_{m+1}-2 u_{m}+u_{m-1}}{\Delta x^{2}}-\frac{\gamma u_{m}}{1+\alpha u_{m}} .
$$

Using the Euler method, the semi-discrete scheme (24) can be discretised further with respect to time $t$, so we obtain the fully-discrete finite difference scheme

$$
u_{m}^{n+1}=u_{m}^{n}+\frac{\Delta t}{\Delta x^{2}}\left(u_{m+1}^{n}-2 u_{m}^{n}+u_{m-1}^{n}\right)-\frac{\gamma u_{m}^{n} \Delta t}{1+\alpha u_{m}^{n}} .
$$

Numerical treatment for the boundary conditions are as follows. The boundary condition at $x=1$ is fixed to be 
$u_{M}=1$. For the boundary condition at $x=0$, we introduce an artificial point $x=-\Delta x$, where the value at this artificial point is $u_{-1}=u_{1}$; this is in order that we enforce $d u / d t=0$, as required by the problem, at the second order accuracy.

\section{B. Runge-Kutta methods for the steady state model}

The steady state model (4) can be written equivalently into a system of two first order ordinary differential equations

$$
\begin{gathered}
\frac{d u}{d x}=v, \\
\frac{d v}{d x}=\frac{\gamma u}{1+\alpha u} .
\end{gathered}
$$

The simplest Runge-Kutta type method for solving system (26)-(27) is the Euler's method given by

$$
\begin{gathered}
u_{m+1}=u_{m}+\Delta x v_{m}, \\
v_{m+1}=v_{m}+\Delta x \frac{\gamma u_{m}}{1+\alpha u_{m}} .
\end{gathered}
$$

The Euler method (28)-(29) is a first order accurate method.

There are many other Runge-Kutta type methods for solving system (26)-(27) with higher order accuracy, such as the second order Heun's method, third order Runge-Kutta method, fourth order Runge-Kutta method, and fifth order Dormand-Prince method. The later is a famous one due to Dormand and Prince [47] which is implemented in the MATLAB software as the ode45 algorithm [48, 49].

It is important to note that Runge-Kutta type methods are applicable for initial value problems. Because our problem is not an initial value one, but it is a boundary value problem, a Runge-Kutta method should be combined with another numerical method for solving the boundary value problem. For example, if we use a shooting method for boundary value problems, then we need to combine an ordinary differential equation solver (such as a Runge-Kutta method) with a rootfinding method. However, this strategy may not be efficient. It is more convenient for us to run the finite difference method for the unsteady state case for a sufficient time; when the solution does not change with respect to time, then we have reached the steady state solution.

\section{NumericAl Results AND Discussion}

In this section we report our numerical experiments and discussion about them. Both the unsteady and steady state cases are considered.

\section{A. Unsteady state experiments}

For the unsteady state experiments, we take $\gamma=1, \alpha=$ $0.1, \Delta x=0.1$, and $\Delta t=0.01 \Delta x$. Results for $t=0.1$, $t=0.3$, and $t=9.0$ are plotted in Figure 1 . We obtain that for $t=0.1$ and $t=0.3$, the system is unsteady. However, for large time, such as $t=9.0$, the system has reached the steady state condition. The steady state condition is observed using the finite difference method in which the solution does not change with respect to time.

When the solution is unsteady, as time evolves, the solution graph moves from below going up until it reaches the steady state condition. This is realistic physically and matches mathematically with the fact that the equilibrium solution $u=0$ is unstable. This means that if there exists a perturbation of the solution around $u=0$, the perturbation moves away from the equilibrium solution $u=0$.

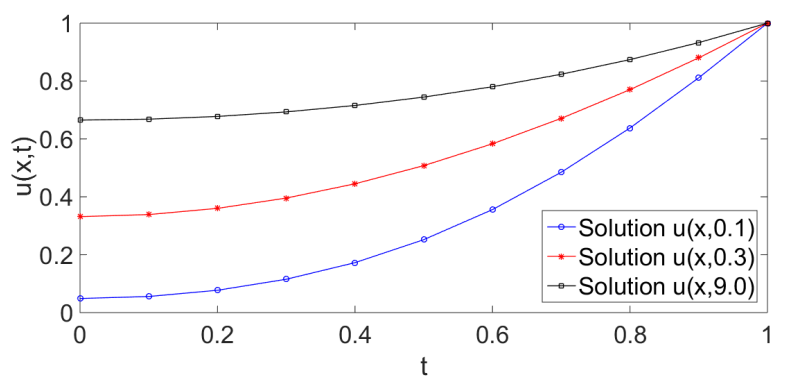

Fig. 1. Numerical results of the unsteady state solutions at time $t=0.1$ and $t=0.3$ together with the steady state solution at $t=9.0$.

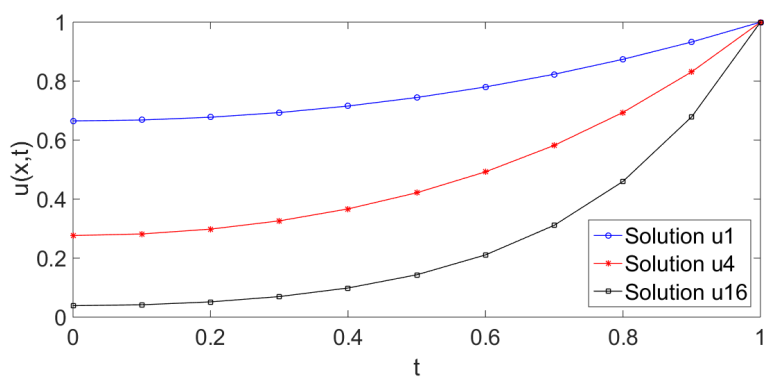

Fig. 2. Numerical results of the steady state solutions. Those for $\gamma=1$ are denoted by $\mathrm{u} 1$, those for $\gamma=4$ are denoted by $\mathrm{u} 4$, and those for $\gamma=16$ are denoted by $\mathrm{u} 16$.

\section{B. Steady state experiments}

For the steady state experiments, we take $\alpha=0.1$. Results for $\gamma=1, \gamma=4$, and $\gamma=16$ are plotted in Figure 2. Here we use the finite difference method for the unsteady state case for a sufficient time; when the solution does not change with respect to time, then we have reached the steady state solution. We use the stopping criterion that the average of absolute difference between two consecutive iterative solutions is less than $10^{-15}$.

We obtain that for steady state solutions, the larger the value of $\gamma$ leads to the lower the concentration of the substrate in the system. This is realistic, because large value of $\gamma$ corresponds to highly reactive system. That is, the substrate has a fast reaction in the system when $\gamma$ is large.

\section{CONCLUSION}

We have solved the reaction-diffusion model using the characteristic and direct-integration methods analytically and finite difference method numerically. The exact solution to the unsaturated steady state case is derived based on the characteristic method for ordinary differential equations. The exact solution to the saturated steady state case is derived based on the direct-integration method. The finite difference method solves both the unsteady and steady state cases. Our results are applicable for electroactive polymer films. This research is limited to one-dimensional problems. Future research direction could model and solve problems in two and/or three dimensions.

\section{ACKNOWLEDGMENT}

Sudi Mungkasi thanks Sanata Dharma University for supporting this research financially. 


\section{REFERENCES}

[1] M. Abjadian and A. Taleei, "Numerical simulation of the biosensors in a trigger mode based on MichaelisMenten enzymatic reaction," Journal of Mathematical Modeling, vol. 8, no. 2, pp. 123-138, 2020.

[2] P. Das, P. Das, and S. Mukherjee, "Stochastic dynamics of Michaelis-Menten kinetics based tumor-immune interactions," Physica A, vol. 541, p. 123603, 2020.

[3] A. Hubert, T. Aquino, H. Tabuteau, Y. Meheust, and T. Le Borgne, "Enhanced and non-monotonic effective kinetics of solute pulses under Michaelis-Menten reactions," Advances in Water Resources, vol. 146, p. 103739, 2020.

[4] K. Min and V. Suseela, "Plant invasion alters the Michaelis-Menten kinetics of microbial extracellular enzymes and soil organic matter chemistry along soil depth," Biogeochemistry, vol. 150, no. 2, pp. 181-196, 2020.

[5] J. Swift, J. M. Alvarez, V. Araus, R. A. Gutierrez, and G. M. Coruzzi, "Nutrient dose-responsive transcriptome changes driven by Michaelis-Menten kinetics underlie plant growth rates," Proceedings of the National Academy of Sciences of the United States of America, vol. 117, no. 23, pp. 12 531-12 540, 2020.

[6] X. Yan, J. J. P. Ruixo, and W. Krzyzanski, "Dose correction for a Michaelis-Menten approximation of a target-mediated drug disposition model with a multiple intravenous dosing regimens," AAPS Journal, vol. 22, no. 2, p. 30, 2020.

[7] K. I. Yun and T. S. Han, "Relationship between enzyme concentration and Michaelis constant in enzyme assays," Biochimie, vol. 176, pp. 12-20, 2020.

[8] M. E. G. Lyons, J. C. Greer, C. A. Fitzgerald, T. Bannon, and P. N. Barlett, "Reaction/diffusion with MichaelisMenten kinetics in electroactive polymer films Part 1. The steady-state amperometric response," Analyst, vol. 121, no. 6, pp. 715-731, 1996.

[9] M. E. G. Lyons, "Reaction/diffusion with MichaelisMenten kinetics in electroactive polymer films Part 2. The transient amperometric response," Analyst, vol. 123, no. 10, pp. 1947-1959, 1998

[10] G. Rahamathunissa and L. Rajendran, "Application of He's variational iteration method in nonlinear boundary value problems in enzyme-substrate reaction diffusion processes: Part 1. The steady-state amperometric response," Journal of Mathematical Chemistry, vol. 44, no. 3, pp. 849-861, 2008.

[11] M. Mahalakshmi and G. Hariharan, "An efficient wavelet based approximation method to steady state reaction-diffusion model arising in mathematical chemistry," Journal of Membrane Biology, vol. 247, no. 3, pp. 263-271, 2014.

[12] J. He, "Variational iteration method for delay differential equations," Communications in Nonlinear Science and Numerical Simulation, vol. 2, no. 4, pp. 235-236, 1997.

[13] _ _ "A new approach to nonlinear partial differential equations," Communications in Nonlinear Science and Numerical Simulation, vol. 2, no. 4, pp. 230-235, 1997.

[14] — , "Approximate analytical solution of Blasius' equation," Communications in Nonlinear Science and Numerical Simulation, vol. 3, no. 4, pp. 260-263, 1998.
[15] S. Mungkasi, "Variational iteration and successive approximation methods for a SIR epidemic model with constant vaccination strategy," Applied Mathematical Modelling, vol. 90, pp. 1-10, 2021.

[16] X. Wang, Q. Xu, and S. N. Atluri, "Combination of the variational iteration method and numerical algorithms for nonlinear problems," Applied Mathematical Modelling, vol. 79, pp. 243-259, 2020.

[17] T. A. El-Sayed and H. H. El-Mongy, "Free vibration and stability analysis of a multi-span pipe conveying fluid using exact and variational iteration methods combined with transfer matrix method," Applied Mathematical Modelling, vol. 71, pp. 173-193, 2019.

[18] —, "Application of variational iteration method to free vibration analysis of a tapered beam mounted on two-degree of freedom subsystems," Applied Mathematical Modelling, vol. 58, pp. 349-364, 2018.

[19] L. Yun-dong and Y. Yi-ren, "Vibration analysis of conveying fluid pipe via He's variational iteration method," Applied Mathematical Modelling, vol. 43, pp. 409-420, 2017.

[20] O. Martin, "A modified variational iteration method for the analysis of viscoelastic beams," Applied Mathematical Modelling, vol. 40, no. 17-18, pp. 7988-7995, 2016.

[21] S. H. Chang, "Convergence of variational iteration method applied to two-point diffusion problems," $A p$ plied Mathematical Modelling, vol. 40, no. 15-16, pp. 6805-6810, 2016.

[22] H. Ghaneai and M. M. Hosseini, "Solving differentialalgebraic equations through variational iteration method with an auxiliary parameter," Applied Mathematical Modelling, vol. 40, no. 5-6, pp. 3991-4001, 2016.

[23] D. Khojasteh Salkuyeh and A. Tavakoli, "Interpolated variational iteration method for initial value problems," Applied Mathematical Modelling, vol. 40, no. 5-6, pp. 3979-3990, 2016.

[24] Y. Zhang and X. J. Yang, "An efficient analytical method for solving local fractional nonlinear PDEs arising in mathematical physics," Applied Mathematical Modelling, vol. 40, no. 3, pp. 1793-1799, 2016.

[25] S. Mungkasi, "Numerical verification of the orders of accuracy of truncated asymptotic expansion solutions to the van der Pol equation," Journal of Mathematical Chemistry, vol. in press, 2020.

[26] P. Roul and V. M. K. Prasad Goura, "A Bessel collocation method for solving Bratu's problem," Journal of Mathematical Chemistry, vol. 58, no. 8, pp. 1601-1614, 2020.

[27] P. Roul and H. Madduri, "An optimal iterative algorithm for solving Bratu-type problems," Journal of Mathematical Chemistry, vol. 57, no. 2, pp. 583-598, 2019.

[28] A. M. Wazwaz, "The variational iteration method for solving systems of third-order Emden-Fowler type equations," Journal of Mathematical Chemistry, vol. 55, no. 3, pp. 799-817, 2017.

[29] N. Das, R. Singh, A. M. Wazwaz, and J. Kumar, "An algorithm based on the variational iteration technique for the Bratu-type and the Lane-Emden problems," Journal of Mathematical Chemistry, vol. 54, no. 2, pp. 527-551, 2016.

[30] M. Singh and A. K. Verma, "An effective computational technique for a class of Lane-Emden equations," Jour- 
nal of Mathematical Chemistry, vol. 54, no. 1, pp. 231251, 2016.

[31] A. Garg, N. G. Reddy, H. Huang, P. Buragohain, and V. Kushvaha, "Modelling contaminant transport in fly ash-bentonite composite landfill liner: mechanism of different types of ions," Scientific Reports, vol. 10, no. 1, p. 11330, 2020.

[32] Y. Gao, S. Pu, C. Zheng, and S. Yi, "An improved method for the calculation of unsaturated-saturated water flow by coupling the FEM and FDM," Scientific Reports, vol. 9, no. 1, p. 14995, 2019.

[33] Y. Rao and Y. Wang, "Seismic waveform simulation for models with fluctuating interfaces," Scientific Reports, vol. 8, no. 1, p. 3098, 2018.

[34] A. I. Alsabery, M. A. Sheremet, A. J. Chamkha, and I. Hashim, "MHD convective heat transfer in a discretely heated square cavity with conductive inner block using two-phase nanofluid model," Scientific Reports, vol. 8, no. 1, p. 7410, 2018.

[35] N. Dostart, Y. Liu, and M. A. Popovic, "Acoustic waveguide eigenmode solver based on a staggered-grid finitedifference method," Scientific Reports, vol. 7, no. 1, p. 17509, 2017.

[36] M. A. Medvedev and T. E. Simos, "A finite difference method with phase-lag and its derivatives equal to zero for problems in chemistry," Journal of Mathematical Chemistry, vol. 58, no. 9, pp. 2024-2060, 2020.

[37] Z. Wang and T. E. Simos, "A finite difference method with zero phase-lag and its derivatives for quantum chemistry problems," Journal of Mathematical Chemistry, vol. 58, no. 8, pp. 1680-1710, 2020.

[38] M. A. Medvedev and T. E. Simos, "New fd scheme with vanished phase-lag and its derivatives up to order six for problems in chemistry," Journal of Mathematical Chemistry, vol. 58, no. 10, pp. 2324-2360, 2020.

[39] J. Lv and T. E. Simos, "A runge-kutta type crowded in phase algorithm for quantum chemistry problems," Journal of Mathematical Chemistry, vol. 57, no. 8, pp. 1983-2006, 2019.

[40] J. E. Macias-Diaz, "An efficient and fully explicit model to simulate delayed activator-inhibitor systems with anomalous diffusion," Journal of Mathematical Chemistry, vol. 57, no. 8, pp. 1902-1923, 2019.

[41] M. Xu and T. E. Simos, "A multistage two-step fraught in phase scheme for problems in mathematical chemistry," Journal of Mathematical Chemistry, vol. 57, no. 7, pp. 1710-1731, 2019.

[42] X. Luo, X. Xu, and H. Rabitz, "Meshless hermite-hdmr finite difference method for high-dimensional dirichlet problems," Journal of Mathematical Chemistry, vol. 57, no. 6, pp. 1652-1669, 2019.

[43] V. Skakauskas, P. Katauskis, and R. Ciegis, "Modelling of the NO + CO reaction over inhomogeneous surfaces," Journal of Mathematical Chemistry, vol. 56, no. 9, pp. 2626-2642, 2018.

[44] I. Alolyan and T. E. Simos, "New three-stages symmetric six-step finite difference method with vanished phase-lag and its derivatives up to sixth derivative for second order initial and/or boundary value problems with periodical and/or oscillating solutions," Journal of Mathematical Chemistry, vol. 56, no. 8, pp. 2267-2301, 2018.
[45] Q. Din, "Bifurcation analysis and chaos control in discrete-time glycolysis models," Journal of Mathematical Chemistry, vol. 56, no. 3, pp. 904-931, 2018.

[46] R. Haberman, Mathematical Models: Mechanical Vibrations, Population Dynamics, and Traffic Flow. Philadelphia: SIAM, 1998.

[47] J. R. Dormand and P. J. Prince, "A family of embedded Runge-Kutta formulae," Journal of Computational and Applied Mathematics, vol. 6, no. 1, pp. 19-26, 1980.

[48] L. F. Shampine and M. W. Reichelt, "The MATLAB ODE suite," SIAM Journal on Scientific Computing, vol. 18, no. 1, pp. 1-22, 1997.

[49] C. Tsitouras, "Explicit Runge-Kutta methods for starting integration of Lane-Emden problem," Applied Mathematics and Computation, vol. 354, pp. 353-364, 2019. 
orginized by:

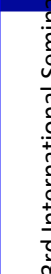

\section{STMIK AKAKOM} Y O G Y A K A R T A

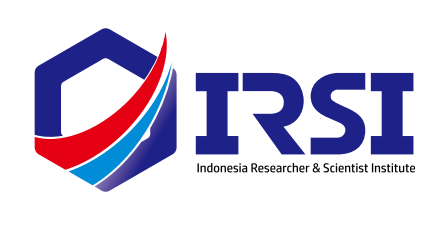

akakom.ac.id

irsi.or.id 




